\title{
ИСПОЛЬЗОВАНИЕ ГЕНОВ Vrn ДЛЯ СОЗДАНИЯ ФОРМ ТРИТИКАЛЕ С РАЗНОЙ ПРОДОЛЖИТЕЛЬНОСТЬЮ ВЕГЕТАЦИОННОГО ПЕРИОДА* (обзор)
}

\section{М.В. ЕМЦЕВА}

Тритикале (× Triticosecale Wittmack) - новая сельскохозяйственная культура, объединяющая в себе ценные свойства пшеницы и ржи. $K$ преимуществам тритикале относятся способность произрастать на бедных, кислых, подтопляемых почвах, более высокое, чем у пшеницы, содержание белка в зерне, устойчивость ко многим грибным заболеваниям. Недостатки тритикале - щуплость зерна, склонность к прорастанию зерна на корню, полеганию, некоторая токсичность зерна вследствие содержания алкилрезорцинолов, а также более длительный по сравнению с родительскими формами вегетационный период. Из всех групп генов наибольшее влияние на продолжительность вегетационного периода злаковых культур оказывают Vrn (response to vernalization, реакция на яровизацию). Яровые растения имеют один или несколько доминантных генов $V r n$, у озимых все гены vrn рецессивные. Мягкая пшеница может иметь гены Vrn-A1, Vrn-B1, Vrn-D1, расположенные соответственно в хромосомах 5AL, 5BL, 5DL (A.J. Worland, 1996), ген Vrn-D4 в околоцентромерном районе хромосомы 5D (N. Kippes с соавт., 2015) и ген Vrn-B3 в хромосоме 7BS (L. Yan c соавт., 2006). У ржи ген $V r n-R 1$ находится в хромосоме $5 \mathrm{RL}$ (J. Plaschke с соавт., 1993). У тритикале были обнаружены доминантные аллели Vrn-A1a, VrnB1a, Vrn-B1b и Vrn-B1c (М. Nowak с соавт., 2014; О.И. Зайцева с соавт., 2015). Ранее эти аллели были выявлены у мягкой пшеницы (D.K. Santra с соавт., 2009; A.B. Shcherban с coaвт., 2012; А.В. Shcherban с соавт., 2015; J. Мilec с соавт., 2013; И.Е. Лихенко с соавт., 2014). На время колошения растений влияет не только изменение нуклеотидной последовательности генов $V r n$, но и изменение числа копий этих генов (A. Diaz с соавт., 2012). Гены Vrn могут влиять на время колошения и в сочетании друг с другом. Так, сорта с тремя доминантными генами Vrn более раннеспелые, чем с одним или двумя доминантными генами Vrn, но имеют наименьшую продуктивность (A.F. Stelmakh, 1993; M. Iqbal с соавт., 2007). Сообщается, что интрогрессия хромосомы 2D укорачивает период вегетации тритикале (А.А. Шишкина, 2008; Л.В. Корень с соавт., 2010). Растения тритикале имеют более длительный вегетационный период, чем исходные линии пшеницы, что может быть вызвано ингибированием генов Vrn геномом ржи (Л.Н. Каминская с соавт., 2005; I.N. Leonova с соавт., 2005). Генетический контроль типа развития спонтанных яровых мутантов в настоящее время не известен. Большинство яровых мутантов позднеспелые, а при посеве осенью в разной степени перезимовывают, что может указывать на то, что они относятся к двуручкам (П.И. Степочкин, 2008; П.И. Степочкин с соавт., 2008). В Сибири озимые тритикале занимают значительные площади, но по яровым тритикале селекция не ведется. Яровые тритикале могут быть использованы для расширения разнообразия яровых культур. Для селекции представляет интерес создание яровых тритикале с разной продолжительностью вегетационного периода.

Ключевые слова: гексаплоидная и октаплоидная тритикале, яровой мутант, пшеница, продолжительность вегетационного периода, гены Vrn.

Тритикале (× Triticosecale Wittmack), или пшенично-ржаной амфиплоид (ПРА), - искусственно созданная культура, полученная при скрещивании пшеницы (Triticum spp.) и ржи (Secale spp.). В зависимости от плоидности различают октаплоидные, гексаплоидные и тетраплоидные тритикале. Октаплоидные тритикале $\left(2 n=56\right.$, геномный состав $A_{1} A_{1} B_{1} B_{1} D D R R$, где $A_{1}$ и $B_{1}$ - геномы мягкой, $A$ и $B$ - геномы твердой пшеницы) получают посредством скрещивания 42-хромосомных пшениц (в основном мягкой пшеницы T. aestivum L.) с рожью (в основном S. cereale L.) и последующего удвоения числа хромосом. Эти ПРА характеризуются цитологической нестабильностью и высокой частотой анеуплоидов. На протяжении ряда поколений у них происходит утрата хромосом до формирования ста-

* Работа была поддержана бюджетным проектом ИЦиГ СО РАН, бюджетный проект № 0324-2015-0005. 
бильного гексаплоидного уровня $(1,2)$. Из-за пониженной озерненности колоса сорта октаплоидных $(\times 8)$ тритикале в сельскохозяйственном производстве не используются. Чтобы поддерживать у таких ПРА нужное число хромосом, необходим постоянный цитологический контроль и отбор типичных растений (3).

Гексаплоидные $(\times 6)$ тритикале $(2 n=42$, геномный состав $A A B B R R)$ получают при скрещивании 28-хромосомных пшениц (в основном твердой пшеницы $T$. durum Desf.) с рожью и последующем удвоении числа хромосом. Эти формы отличаются более высокой цитологической стабильностью по сравнению с $\times 8$ тритикале.

Гексаплоидные и октаплоидные тритикале относятся к первичным, то есть создаваемым посредством удвоения числа хромосом у пшеничноржаных гибридов $F_{1}$ между гексаплоидной или тетраплоидной пшеницей и рожью. Однако большинство сортов - это вторичные гексаплоидные тритикале, полученные от скрещивания тритикале $\times 8$ и $\times 6$ или скрещивания тритикале $\times 6$ с пшеницей. Во втором поколении из-за разнокачественности геномов $A$ и $B$ мягкой и твердой пшениц происходит формообразовательный процесс, в результате которого среди различных генотипов встречаются растения с повышенной продуктивностью и значительным сокращением частоты нарушений в мейозе (4).

Тетраплоидные $(\times 4)$ тритикале $(2 n=28)$ впервые получены в результате опыления пшенично-ржаных гибридов $F_{1}$ рожью. Среди гибридов $\mathrm{F}_{2}$ было выделено растение с 28 хромосомами, содержащее 14 хромосом пшеницы и 14 хромосом ржи (5). Урожай тритикале $\times 4$ очень низкий, ценных форм среди них нет. Однако отмечается, что тритикале $\times 4$ более цитологически стабильны, чем $\times 8$ и $\times 6$, следовательно, возможно повышение их фертильности методами селекции (5).

В настоящем обзоре рассматривается разнообразие генов и аллелей, контролирующих тип развития тритикале и ее родительских форм пшеницы и ржи, с использованием которых возможно создавать сорта, подходящие для выращивания в регионах с разной продолжительностью вегетационного периода.

Тритикале имеет ряд положительных качеств. Хотя пшеницу скрестили с рожью главным образом для того, чтобы передать ей зимостойкость ржи, тритикале по этому признаку, как правило, не отличается от озимой пшеницы. Предполагается, что это связано с подавлением активности хромосом ржи цитоплазмой пшеницы (6). По некоторым данным, $\times 8$ тритикале более зимостойки, чем ×6 (7), однако снижение плоидности с $\times 8$ до $\times 6$ приводило к увеличению морозостойкости культуры (8). При сравнении тритикале с исходными линиями пшеницы было установлено, что тритикале более зимостойки за счет присутствия у них хромосом ржи (9). С использованием молекулярных маркеров у гексаплоидных тритикале идентифицированы три локуса зимостойкости на хромосомах $5 \mathrm{~A}, 1 \mathrm{~B}$ и $5 \mathrm{R}(10)$.

Преимущество тритикале, как и ржи, перед пшеницей - способность произрастать на кислых, малоплодородных, подтопляемых почвах. Тритикале более устойчивы ко многим грибным заболеваниям: мучнистой росе, желтой ржавчине и головне. Как и рожь, тритикале поражается бурой ржавчиной (причем растения $\times 8$ сильнее, чем $\times 6$ ), стеблевой ржавчиной, спорыньей, корневыми гнилями и снежной плесенью (7).

Еще одно ценное свойство тритикале - более высокое, чем у пшеницы, содержание белка в зерне. Однако вследствие низкого качества 
клейковины мука тритикале по хлебопекарным качествам уступает муке пшеницы, поэтому ее используют в смеси с мукой пшеницы в количестве 30-50\%. В этом случае улучшается эластичность и увеличивается объем хлеба (11). Хлеб с добавлением муки тритикале по питательной ценности превосходит пшеничный и ржаной, а также обладает характерным сладковатым вкусом. С использованием муки тритикале изготовляют макаронные изделия, печенье, бисквиты, крекеры, диетический хлеб для людей, страдающих нарушением обмена веществ. Одним из способов улучшения хлебопекарных качеств тритикале считается замещение хромосомы $1 \mathrm{R}$ ржи на гомеологичную хромосому 1D пшеницы (12). Потенциальный интерес для улучшения хлебопекарных качеств тритикале представляет также замещение хромосомы 1R ржи на хромосому 1U Aegilops umbellulata (13).

Зерно тритикале используется в пивоваренной и спиртовой промышленности. Выход спирта в этом случае на 3-5 \% больше, чем из зерна других зерновых (14). Успешные результаты показаны при применении тритикале в качестве зернофуражной и кормовой культуры. Зерно тритикале - высокобелковый корм с лучшей перевариваемостью, чем зерно пшеницы и ячменя. Зеленая масса тритикале благодаря повышенному содержанию сахаров и каротиноидов поедается скотом лучше, чем пшеничная и ржаная, ее употребление положительно сказывается на продуктивности сельскохозяйственных животных (рост удоев молока и содержания в нем жиров, увеличение привеса животных) (7).

Однако, кроме достоинств, тритикале имеет и некоторые недостатки. У первичных тритикале наблюдается пониженная озерненность колоса. Причиной этого становятся нарушения в мейозе, которые ведут к возникновению анеуплоидных растений и, следовательно, снижению продуктивности (15). Показано, что присутствие в геноме пшеницы лишь одной хромосомы ржи вызывает структурные изменения в кариотипе (16). Проблема пониженной озерненности ПРА решается с помощью селекции.

Тритикале имеет шуплое, плохо выполненное зерно вследствие нарушения в накоплении мелкозернистого крахмала, а также преждевременного высвобождения $\alpha$-амилазы и разложения ею крахмала (17). Содержание белка в зерне обратно коррелирует с его выполненностью, из-за чего селекция на выполненность зерна приводит к уменьшению содержания в нем белка, и наоборот (7). Активность $\alpha$-амилазы определяет еще один недостаток тритикале - склонность к прорастанию зерна на корню, что снижает качество и урожайность. Показано, что устойчивость к прорастанию зерна на корню повышается при наличии хромосомного замещения 2R/2D (18).

Большинство сортов тритикале длинностебельные и склонны к полеганию. При этом предрасположенность к полеганию отмечается у растений высотой более 91 см (19). Растения с замещением 2R/2D имеют менышую высоту, чем другие растения $(20,21)$. Есть данные, что замещение хромосомы 2R ржи на хромосому 2U Aegilops umbellulata приводило к снижению высоты у гибридов тритикале (13).

Один из недостатков тритикале - токсичность зерна вследствие наличия в нем антиметаболитов алкилрезорцинолов. По содержанию этих веществ тритикале занимает промежуточное положение между пшеницей и рожью. Наличие в корме зерна тритикале в количестве более 50 \% тормозит прирост массы животных, может вызвать у них заболевание печени и слизистой оболочки желудка. Количество алкилрезорцинолов снижается при технологической обработке зерна и приготовлении кормосмесей (5). 
Тритикале имеет более длительный, чем у родительских форм, вегетационный период. Известно, что вегетационный период полиплоидов увеличивается с повышением плоидности (5). Более того, вследствие гибридного происхождения многие биологические процессы у тритикале протекают медленнее, чем у пшеницы (7). Период от колошения до цветения у этой культуры на несколько суток длиннее, чем у пшеницы (5). Фаза тестообразной спелости у тритикале продолжительна и у некоторых образцов может длиться до 3 нед (5). Созревают тритикале на 3-20 сут позже пшеницы $(7,8)$. По длительности периода до колошения тритикале ×6 занимают промежуточное положение между мягкой пшеницей и тритикале $\times 8(3,22)$, а гибриды $\mathrm{F}_{1}$ между пшеницей и рожью, наоборот, характеризуются ускоренным по сравнению с пшеницей развитием (5). У озимой ржи выше скорость роста и степень развития апекса, чем у пшеницы, а тритикале по этому признаку ближе ко ржи, чем к пшенице (23).

По типу развития пшеница, рожь и тритикале могут быть яровыми, озимыми и двуручками (24). Озимым растениям для перехода к генеративному развитию требуется длительный (1-3 мес) период воздействия низкими положительными температурами - яровизация; яровые культуры способны перейти к колошению без нее. Двуручки могут развиваться как по яровому, так и по озимому типу. Время наступления генеративного развития и время колошения - важные адаптивные признаки. Тип развития, а также продолжительность вегетационного периода контролируются генами Vrn (response to vernalization, реакция на яровизацию).

У мягкой пшеницы гены Vrn-A1, Vrn-B1, Vrn-D1 расположены соответственно в хромосомах 5AL, 5BL и 5DL $(25,26), V r n-D 4$ - в околоцентромерном районе хромосомы $5 \mathrm{D}(27,28), V r n-B 3-$ в хромосоме $7 \mathrm{BS}$ (29). Ген Vrn-R1 ржи локализован в хромосоме 5RL (30). Яровой тип развития контролируется одним или несколькими доминантными генами Vrn, озимый тип - рецессивными генами vrn во всех этих локусах (31). Двуручки могут иметь доминантные гены Vrn-B1 (32), Vrn-D1, Vrn-D4 (33-36) или «слабый» аллель доминантного гена $V r n-A 1$ (37).

На примере замещенных и изогенных линий пшеницы показано, что доминантный ген $V r n-A 1$ эпистатичен по отношению к остальным генам $V r n$ и определяет отсутствие реакции на яровизацию, в то время как растения с генами Vrn-B1, Vrn-D1, Vrn-D4 и Vrn-B3 в разной степени реагируют на яровизацию ускорением колошения $(31,38,39)$. По степени влияния на время колошения гены Vrn можно расположить в следующей последовательности: $V r n-A 1>V r n-D 1>V r n-D 4>V r n-B 1$, где растения с доминантным геном $V r n-A 1$ самые ранние, а с доминантным геном $V r n-B 1$ самые поздние $(40,41)$. Среди сортов пшеницы Китая растения с доминантным геном $V r n-D 1$, наоборот, созревают позже растений с $V r n-B 1$, что можно объяснить наличием разных аллелей $V r n-D 1$ (34). Доминантный ген $V r n-B 3$ в комбинации с другими генами Vrn определяет очень раннее колошение (34).

Локусы $V r n$ характеризуются множественным аллелизмом в результате различий в строении регуляторных районов - промотора или первого интрона. Для обнаружения аллелей генов Vrn были разработаны праймеры к этим районам. Ген $V r n-A 1$ мягкой пшеницы имеет аллели $V r n-A 1 a$ (инсерция и дупликация в промоторном районе), $V r n-A l b$ (делеция 20 п.н. в промоторном районе) (42) и $V r n-A 1 c$ (делеция 5504 п.н. в первом интроне) (43). У тетраплоидной пшеницы обнаружены аллели Vrn-Ald, Vrn-Ale и $V r n-A 1 f$ (делеции соответственно 32, 54 и 50 п.н. в промоторном районе) 
$(42,44)$, у диплоидной пшеницы - аллели $V r n-A^{m} l f, V r n-A^{m} l g, V r n-A^{m} l h$, имеющие делеции и/или инсерции в промоторном районе и/или первом интроне (45). У гексаплоидной пшеницы T. compactum выявлен новый вариант доминантного аллеля Vrn-Ala, характеризующийся наличием делеции 16 п.н. и четырех однонуклеотидных полиморфизмов (ОНП, singlenucleotide polymorphisms, SNPs) в последовательности мобильного генетического элемента в промоторе, а также новый аллель $V r n-A 1 j$, содержащий делецию 54 п.н. в области промотора (46). У образцов тетраплоидных пшениц T. turgidum и T. durum обнаружен аллель Vrn-Ali с ОНП в последовательности аденинового (А) тракта VRN-бокса гена Vrn-A1, предположительно определяющий пониженную чувствительность к яровизации и факультативный тип развития (46). У пшениц $\times 4$ и $\times 6$ идентифицированы пять вариантов аллеля $V r n-A 1 b$, различающихся по полиморфизму А-тракта и С-обогащенного сегмента в последовательности VRN-бокса (46). У образцов $T$. dicoccum обнаружен доминантный аллель $V r n-A 1 k$, ответственный за снижение потребности в яровизации и яровой тип развития, несущий делецию 42 п.н. в области промотора (47).

У гена Vrn-B1 мягкой пшеницы идентифицированы аллели Vrn-Bla (делеция 6850 п.н. в первом интроне) (43), $V r n-B 1 b$ (отличается от аллеля $V r n-B 1 a$ дополнительной делецией 36 п.н. в первом интроне) (48), Vrn-B1c (кроме делеции, описанной у аллеля $V r n-B l a$, несет в первом интроне делецию 820 п.н. и дупликацию 431 п.н., перемещенную в начало этой делеции) (49, 50). У тетраплоидных пшениц T. turgidum и T. turanicum Jakubz. в промоторных областях доминантного гена Vrn-B1 обнаружены делеции размером соответственно 5463 п.н. и 127 п.н. (44, 51). У пшеницы $\times 4$ T. carthlicum выявлен аллель Vrn-B1(ins), характеризующийся инсерцией ретротранспозона в промоторной области (46). У Vrn-B1 обнаружены два варианта, отличающиеся делециями 7 п.н., 3 п.н., 2 п.н. и 8 ОНП от рецессивного аллеля vrn-B1 (46).

Аллель Vrn-Dla яровых мягких пшениц имеет делецию 4235 п.н. в первом интроне (43). Аллель Vrn-D1b двуручек отличается от Vrn-D1a однонуклеотидной заменой в промоторной области (36). В трех сортах мягкой пшеницы из Китая обнаружен аллель $V r n-D 1 c$, имеющий инсерцию 174 п.н. в промоторном районе (52). У Aegilops tauschii выявлен аллель $V r n-D^{t} 1$, характеризующийся делецией 5437 п.н. в первом интроне (53), у T. spelta и T. compactum - Vrn-DIs с инсерцией 844 п.н. в первом интроне (54). У пяти образцов пшеницы $\times 6$ обнаружены два гаплотипа гена Vrn-D1 - Нар-7Тu и Нар-8Т, различающиеся протяженностью Т-тракта в позиции -428 п.н. (55). Ген Vrn-D4 образовался в результате инсерции участка хромосомы 5AL размером 290 т.п.н., несущего ген Vrn-A1, в короткое плечо хромосомы $5 \mathrm{D}$ (56).

Аллель Vrn-B3a в замещенной линии Chinese Spring/Hope 7В имеет инсерцию 5295 п.н. в промоторном районе (29), аллель Vrn-B3b - инсерцию 890 п.н. в промоторе рецессивного гена $v r n-B 3$, а аллель $V r n-B 3 c-$ делеции 20 п.н. и 4 п.н. в промоторе доминантного гена $V r n-B 3 a(57)$.

С использованием аллель-специфичных маркеров у тритикале были обнаружены доминантные аллели Vrn-Ala, Vrn-Bla, Vrn-B1b, Vrn-B1c $(58,59)$, ранее выявленные у мягкой пшеницы $(48,60-63)$.

В последнее время сообщается, что на скорость выколашивания пшеницы может влиять не только изменение нуклеотидной последовательности генов Vrn, но и увеличение числа их копий. Так, увеличение числа копий доминантного аллеля гена Vrn-A1 до двух и трех вызывало 
задержку индукции цветения по сравнению с растениями дикого типа, несущими одну копию $V r n-A 1$ (64).

Доминантные гены Vrn могут влиять на продолжительность вегетационного периода в комбинации друг с другом. Сорта, в генотипах которых присутствуют два гена Vrn, выколашиваются раньше, чем сорта с одним доминантным геном, а сорта, обладающие тремя генами Vrn, - caмые скороспелые, но имеют наименьшую продуктивность $(65,66)$. Сорта тритикале с более ранним выколашиванием характеризуются высокой фертильностью колоса и массой 1000 зерен (67).

Доминантные гены Vrn неодинаково влияют на продолжительность вегетационного периода главным образом за счет того, что они определяют разную длительность II этапа органогенеза (фаза кущения) $(41,68)$. Так, у раннеспелых генотипов с одним доминантным геном $V r n-A 1$ ( Vrn-A1 vrn-B1 vrn-D1) и двумя доминантными генами (Vrn-A1 Vrn-B1 vrn$D 1$ и $V r n-A 1$ vrn-B1 Vrn-D1) она наименьшая, а у позднеспелой линии с одним доминантным геном $V r n-B 1$ - наибольшая (68). При этом чем короче период вегетативного развития растений, тем длиннее период от колошения до созревания, и наоборот $(41,69)$. У тритикале в разных хромосомах были обнаружены локусы, влияющие на скорость развития растений (70).

Гены Vrn связаны с формированием элементов продуктивности пшеницы опосредованно - через участие в регуляции углеводного и азотного обмена $(71,72)$.

Л.В. Корень и Л.В. Хотылева отмечают (73), что наиболее раннеспелыми из всех изученных ими линий были тритикале $\times 6$ с интрогрессией хромосомы 2D мягкой пшеницы. В другой работе также сообщается, что линии тритикале с замещением хромосом 2R/2D характеризовались достоверно более коротким периодом вегетации по сравнению с линиями, имевшими полный комплект хромосом, а линии тритикале с замещением 2B/2D и транслокацией T:2RS.2RL-2BL были менее скороспелыми, чем формы с замещением 2R/2D (21).

Многие исследователи при посеве весной озимых культур пшеницы, ржи и тритикале наблюдали спонтанное появление среди них яровых растений $(74,75)$. Генетический контроль типа развития спонтанных яровых мутантов в настоящее время не известен, но предполагается, что причиной их возникновения становятся либо мутации в промоторном районе или первом интроне генов $\operatorname{Vrn}(42,43)$, либо эпигенетическое изменение состояния хроматина в этих районах, не затрагивающее последовательность ДНК $(76,77)$. В обоих случаях рецессивные гены vrn переходят в доминантное состояние, в результате чего запускается генеративное развитие (78). Установлено, что тип развития спонтанных яровых мутантов определяется доминантным геном, находящимся в гетерозиготе, так как в потомстве от самоопыления мутантов происходит расщепление на яровые и озимые формы (8). В популяции $\mathrm{F}_{2}$, полученной от скрещивания между собой мутантных яровых растений ржи, наблюдалось расщепление на яровые и озимые, близкое к 3:1, что указывает на моногенный доминантный контроль признака яровости (8). В популяции озимого сорта пшеницы Лютесценс 105 было выделено два яровых мутанта, различавшихся по длительности вегетации почти на месяц. При генетическом анализе поколения $F_{2}$ этих мутантов наблюдалось расщепление на яровые и озимые растения, близкое к 15:1. Следовательно, гены, определяющие тип развития изученных мутантов, находятся в разных локусах (8).

Самые ранние спонтанные яровые мутанты озимых тритикале вы- 
колашивались в конце июля - начале августа, но большинство мутантов были позднеспелыми и выколашивались в сентябре (75). Кроме этого, все спонтанные яровые мутанты пшеницы, ржи и тритикале, посеянные осенью, в разной степени перезимовывают. Следовательно, можно предположить, что они относятся к двуручкам (8).

Частота появления яровых мутантов увеличивалась при удлинении срока хранения семян, а также при повышении температуры в июне и количества осадков в июле (75). Предполагается, что эти стрессы активируют мобильные элементы, которые могут приводить к мутациям в генах Vrn (75). Имеются данные о влиянии физических и химических мутагенов на продолжительность вегетационного периода яровых растений (79-81).

В Институте генетики и цитологии Беларуси созданы линии октаплоидных и гексаплоидных тритикале с доминантными генами Vrn (22). В качестве материнских форм при этом были использованы изогенные линии мягкой пшеницы с доминантными аллелями Vrn-A1, Vrn-B1 и Vrn-D1, полученные на основе сортов Triple Dirk, Мироновская 808 и Безостая 1, a в качестве опылителя - сорт озимой диплоидной ржи Восход и яровая аллоплазматическая рожь (22). При изучении этих линий обнаружено ингибирующее действие генетической среды тритикале на проявление доминантных генов Vrn: у тритикале растения выколашивались позднее, чем у соответствующих линий пшеницы. При этом доминантный ген Vrn-A1, определяющий раннее выколашивание, подавлялся в большей степени, чем $V r n-B 1$ и Vrn-D1 (22, 82). Позднее в Сибирском НИИ растениеводства и селекции СО РАСХН были созданы октаплоидные линии тритикале с доминантными генами Vrn посредством скрещивания изогенных по генам $V r n-A 1, V r n-B 1, V r n-D 1$ и Vrn-D4 линий мягкой пшеницы Triple Dirk c озимой диплоидной рожью сорта Короткостебельная 69. Доминантные гены $V r n$ в этих линиях тритикале по степени влияния на время колошения располагались в такой же последовательности, как и у линий пшеницы с этими генами (3).

Таким образом, тритикале - перспективная для возделывания культура, обладающая способностью произрастать на бедных почвах и устойчивостью к ряду грибных болезней, с более высоким, чем у пшеницы, содержанием белка в зерне, большим выходом спирта и морозостойкостью. Наибольшее влияние на продолжительность вегетационного периода пшеницы, ржи и тритикале оказывают гены реакции на яровизацию $V r n$. Эти гены в разной степени влияют на время колошения и эффект при яровизации растений. У генов Vrn выявлен ряд аллелей, различающихся по наличию мутаций в промоторном районе и/или первом интроне, которые увеличивают разнообразие растений по длительности вегетационного периода и реакции на яровизацию. С использованием аллель-специфичных праймеров у тритикале были обнаружены аллели Vrn-Ala, Vrn-Bla, $V r n-B 1 b$ и $V r n-B 1 c$, ранее выявленные у мягкой пшеницы. Кроме этого, посредством изменения числа копий генов Vrn или комбинирования друг с другом разных доминантных генов Vrn можно манипулировать длиной вегетационного периода растений. При посеве весной озимых тритикале, пшеницы и ржи наблюдалось появление среди них спонтанных яровых растений. В настоящее время показано, что тип развития таких спонтанных яровых мутантов определяется доминантным геном, находящимся в гетерозиготе, поскольку в потомстве от их самоопыления происходит расщепление на яровые и озимые формы. В Сибири возделываются озимые сорта тритикале. В связи с непредсказуемым изменением климата и по- 
вышением спроса на фуражное зерно в животноводстве представляет интерес создание яровых форм тритикале, различающихся по длине вегетационного периода, для выращивания в качестве подстраховочной культуры. Такие формы могут быть получены на основе разных доминантных аллелей Vrn и их сочетаний.

\title{
Автор благодарит П.И. Степочкина за замечания, высказанные при доработ- ке рукописи статьи.
}

\author{
Сибирский НИИ растениеводства и селекции - \\ филиал ФГБНУ Федеральный исследовательский иентр \\ Институт иитологии и генетики Сибирского отделения \\ Поступила в редакцию \\ Российской академии наук, \\ 630501 Россия, Новосибирская обл., пос. Краснообск, \\ ул. С-100, зд. 21, а/я 375, \\ e-mail: emtseva@bionet.nsc.ru $₫$ \\ Sel’skokhozyaistvennaya biologiya [Agricultural Biology], 2020, V. 55, № 1, pp. 3-14 \\ 7 октября 2019 года

\section{THE USE OF Vrn GENES FOR CREATION OF TRITICALE FORMS WITH DIFFERENT LENGTH OF VEGETATION PERIOD (review)}

\section{M.V. Emtseva}

Siberian Research Institute for Plant Industry and Breeding - Branch of the Institute of Cytology and Genetics, Siberian branch RAS, 21 ul. C-100, Novosibirsk Province, Krasnoobsk, PO Box 375, 630501 Russia, e-mail emtseva@bionet.nsc.ru ( $\square$ corresponding author)

ORCID:

Emtseva M.V. orcid.org/0000-0003-3911-8551

The authors declare no conflict of interests

Acknowledgements:

The author thanks P.I. Stepochkin for the notes during the revision of the article.

Supported financially by the budget project of the Institute of Cytology and Genetics SB RAS, budget project No. 0324-2015-0005

Received October 7, 2019

doi: 10.15389/agrobiology.2020.1.3eng

\section{Abstract}

The advantages and disadvantages of triticale culture are briefly reviewed. The control of the length of vegetative period of spring triticale forms and spontaneous spring triticale mutants is viewed more particularly. Triticale ( $\times$ Triticosecale Wittmack) is a new agricultural culture that combines valuable traits of wheat and rye. The advantages of triticale are its ability to grow on poor, acid, waterlogged soils; higher, than in wheat, content of protein in grains; its resistance to many fungus diseases. The disadvantages are undersized grains, its tendency to sprouting, lodging, a partial toxicity of grains due to the presence of alkylresorcinols, and a longer, compared to parental forms, vegetation period. The biggest influence on the length of the vegetation period of cereals have vernalization response genes - Vrn. Spring plants have one or more dominant Vrn genes, in winter plants all vrn genes are recessive. Common wheat carries genes $V r n-A 1, V r n-B 1, V r n-D 1$, located on the chromosomes 5AL, 5BL, 5DL respectively (A.J. Worland, 1996), Vrn-D4 gene, located on the centromeric region of chromosome 5D (N. Kippes et al., 2015) and $V r n-B 3$ gene on the chromosome 7BS (L. Yan et al., 2006). Rye has Vrn-R1 gene on the chromosome 5RL (J. Plaschke et al., 1993). In triticale there were detected $V r n-A 1 a, V r n-B 1 a, V r n-B 1 b$ and $V r n-B 1 c$ alleles (M. Nowak et al., 2014; O.I. Zaitseva et al., 2015). The same alleles were detected previously in common wheat (D.K. Santra et al., 2009; A.B. Shcherban et al., 2012, 2015; J. Milec et al., 2013; I.E. Likhenko et al., 2014). Heading time of plants can be influenced not only by an alteration of nucleotide sequence of $\mathrm{Vrn}$ genes, but also by a change of the copy number of these genes (A. Diaz et al., 2012). Vrn genes can influence heading time in the combination with each other. For example, cultivars with three dominant $V r n$ genes are ripening earlier, than cultivars with one or two dominant $V r n$ genes, but they have the least productivity (A.F. Stelmakh, 1993; M. Iqbal et al., 2007). It was also reported, that introgression of chromosome 2D shortened the period of triticale vegetation (A.A. Shishkina, 2008; L.V. Koren et al., 2010). Triticales have more prolonged vegetation period compared to parental wheat lines, which can be due to the inhibition of the $V r n$ genes by rye genome (L.N. Kaminskaya et al., 2005; I.N. Leonova et al., 2005). The genetic control of growth habit of spontaneous spring mutants is currently unknown. It was determined, that the majority of spring mutants are late ripening, 
and, after autumn sowing, they survive in different extent, what can mean, that they are facultative (P.I. Stepochkin, 2008; P.I. Stepochkin et al., 2008). In Siberia winter triticales occupy considerable areas, but the breeding of spring triticales hasn't been carried on yet. Spring triticales could increase biodiversity of spring cultures. Thereby creation of spring triticales with different length of vegetative period is of great breeding interest.

Keywords: hexaploid and octoploid triticale, spontaneous spring mutant, wheat, length of vegetative period, $\operatorname{Vrn}$ genes.

\section{R E F E R E N C ES}

1. Ma X.-F., Gustafson J.P. Allopolyploidization-accommodated genomic sequence changes in triticale. Annals of Botany, 2008, 101(6): 825-832 (doi: 10.1093/aob/mcm331).

2. Kalinka A., Achrem M. Reorganization of wheat and rye genomes in octoploid triticale (×Triticosecale). Planta, 2018, 247(4): 807-829 (doi: 10.1007/s00425-017-2827-0).

3. Stepochkin P.I. Sibirskii vestnik sel'skokhozyaistvennoi nauki, 2009, 11(203): 26-32 (in Russ.).

4. Dubovets N.I., Sycheva E.A., Solovei L.A., Shtyk T.I., Bondarevich E.B. Vestsi Natsyyanal'nai akademii navuk Belarusi. Seryya biyalagichnykh navuk, 2013, 4: 35-44 (in Russ.).

5. Sechnyak L.K., Sulima Yu.G. Tritikale [Triticale]. Moscow, 1984 (in Russ.).

6. Limin A.E., Dvorak J., Fowler D.B. Cold hardiness in hexaploid Triticale. Canadian Journal of Plant Science, 1985, 65(3): 487-490 (doi: 10.4141/cjps85-070).

7. Makhalin M.A. Mezhrodovaya gibridizatsiya zernovykh kolosovykh kul'tur [Intergeneric hybridization of cereal crops]. Moscow, 1992 (in Russ.).

8. Stepochkin P.I. Formoobrazovatel'nye protsessy $v$ populyatsiyakh triticale [Natural selection in triticale populations]. Novosibirsk, 2008 (in Russ.).

9. Khotyljova L.V., Kaminskaya L.N., Koren L.V. Influence of genetic systems of $V R N$ - and $P P D$ genes on the ecological adaptation of wheat and Triticale. Biologija, 2002, 4: 45-48.

10. Liu W., Maurer H.P., Li G., Tucker M.R., Gowda M., Weissmann E.A., Hahn V., Würschum T. Genetic architecture of winter hardiness and frost tolerance in Triticale. PLoS ONE, 2014, 9(6): e99848 (doi: 10.1371/journal.pone.0099848).

11. Goryanina T.A. Dostizheniya nauki i tekhniki APK, 2011, 12: 30-32 (in Russ.).

12. Krupin P.Yu., Divashuk M.G., Khomyakova O.V., D'yachuk T.I., Karlov G.I. Izvestiya TSKHA, 2009, 3: 74-80 (in Russ.).

13. Adonina I.G., Orlovskaya O.A., Tereshchenko O.YU., Koren' L.V., Khotyleva L.V., Shumnyi V.K., Salina E.A. Genetika, 2011, 47(4): 516-526 (in Russ.).

14. Zasorina E.V., Gorchin S.A., Golikova I.A. Vestnik Kurskoi gosudarstvennoi sel'skokhozyaistvennoi akademii, 2013, 6: 66-68 (in Russ.).

15. Khomyakova O.V. Agrarnyi vestnik Yugo-Vostoka, 2010, 1(4): 18-21 (in Russ.).

16. Silkova O.G., Loginova D.B., Ivanova (Kabanenko) Yu.N., Bondarevich E.B., Solovei L.A., Shtyk T.I., Dubovets N.I. Vavilovskii zhurnal genetiki i selektsii, 2014, 18(4/1): 630-642 (in Russ.).

17. Sokol N.V., Donchenko L.V., Khramova N.S., Kovtunenko V.Ya., Grishchenko S.A. Izvestiya vysshikh uchebnykh zavedenii. Pishchevaya tekhnologiya, 2006, 1(290): 38-39 (in Russ.).

18. Bazhenov M.S., Divashuk M.G., Pyl'nev V.V., Karlov G.I., Rubets V.S. Izvestiya TSKHA, 2011, 2: 20-26 (in Russ.).

19. Khudenko M.A. Sravnitel'naya kharakteristika obraztsov yarovoi tritikale kollektsii VIR v usloviyakh Krasnoyarskoi lesostepi. Kandidatskaya dissertatsiya [Comparative characteristics of spring triticale samples of the VIR collection in the conditions of the Krasnoyarsk forest-steppe. PhD Thesis]. Krasnoyarsk, 2014 (in Russ.).

20. Kurkiev K.U. Genetika, 2008, 44(9): 1238-1245 (in Russ.).

21. Shishkina A.A., Dedkova O.S. Materialy Mezhdunarodnoi nauchnoi shkoly-konferentsii molodykh uchenykh «Genetika i selektsiya rastenii, osnovannaya na sovremennykh geneticheskikh znaniyakh $i$ tekhnologiyakh» [Proc. Int. scientific school-conference of young scientists «Genetics and plant breeding based on modern genetic knowledge and technologies»]. Zvenigorod, 2008: 78 (in Russ.).

22. Kaminskaya L.N., Koren' L.V., Leonova I.N., Adonina I.G., Khotyleva L.V., Salina E.A. Vestnik VOGiS, 2005, 9(4): 481-489 (in Russ.).

23. Petr J., Hradecká D.H. Peculiarities of the growth and development of triticale in comparison with wheat and rye. Czech Journal of Genetics and Plant Breeding, 2005, 41 (Special Issue): 213.

24. Alheit K.V., Maurer H.P., Reif J.C., Tucker M.R., Hahn V., Weissmann E.A., Würschum T. Genome-wide evaluation of genetic diversity and linkage disequilibrium in winter and spring triticale ( $\times$ Triticosecale Wittmack). BMC Genomics, 2012, 13(1): 235 (doi: 10.1186/1471-216413-235).

25. Maistrenko O.I. V sbornike: Ontogenetika vysshikh rastenii [Ontogenetics of higher plants]. Kishinev, 1992: 98-114 (in Russ.). 
26. Worland A.J. The influence of flowering time genes on environmental adaptability in European wheats. Euphytica, 1996, 89(1): 49-57 (doi: 10.1007/BF00015718).

27. Yoshida T., Nishida H., Zhu J., Nitcher R., Distelfeld A., Akashi Y., Kato K., Dubcovsky J. $V r n-D 4$ is a vernalization gene located on the centromeric region of chromosome $5 \mathrm{D}$ in hexaploid wheat. Theoretical and Applied Genetics, 2010, 120(3): 543-552 (doi: 10.1007/s00122-0091174-3).

28. Kippes N., Zhu J., Chen A., Vanzetti L., Lukaszewski A., Nishida H., Kato K., Dvorak J., Dubcovsky J. Fine mapping and epistatic interactions of the vernalization gene $V R N-D 4$ in hexaploid wheat. Molecular Genetics and Genomics, 2014, 289(1): 47-62 (doi: 10.1007/s00438-0130788-y).

29. Yan L., Fu D., Li C., Blechl A., Tranquilli G., Bonafede M., Sanchez A., Valarik M., Dubcovsky J. The wheat and barley vernalization gene $\mathrm{Vrn}-3$ is an orthologue of FT. Proceedings of the National Academy of Sciences, 2006, 103(51): 19581-19586 (doi: 10.1073/pnas.0607142103).

30. Plaschke J., Börner A., Xie D.X., Koebner R.M.D., Schlegel R., Gale M.D. RFLP mapping of genes affecting plant height and growth habit in rye. Theoretical and Applied Genetics, 1993, 85(8): 1049-1054 (doi: 10.1007/BF00215046).

31. Pugsley A.T. Additional genes inhibiting winter habit in wheat. Euphytica, 1972, 21(3): 547-552 (doi: 10.1007/BF00039355).

32. Fait V.I., Gubich E.Yu., Zelenina G.A. Razlichiya sortov dvuruchek myagkoi pshenitsy po genam Vrn-1 tipa razvitiya. Plant Varieties Studying and Protection, 2018, 14(2): 160-169 (doi: 10.21498/2518-1017.14.2.2018.134762) (in Russ.).

33. Filobok V.A., Guenkova E.A., Bespalova L.A., Koshkin V.A., Potokina E.K. Zernovoe khozyaistvo Rossii, 2016, 1: 38-42 (in Russ.).

34. Zhang X.K., Xiao Y.G., Zhang Y., Xia X.C., Dubcovsky J., He Z.H. Allelic variation at the vernalization genes $V r n-A 1, V r n-B 1, V r n-D 1$ and $V r n-B 3$ in Chinese wheat cultivars and their association with growth habit. Crop Science, 2008, 48(2): 458-470 (doi: 10.2135/cropsci2007.06.0355).

35. Sun Q.-M., Zhou R.-H., Gao L.-F., Zhao G.-Y., Jia J.-Z. The characterization and geographical distribution of the genes responsible for vernalization requirement in Chinese bread wheat. Journal of Integrative Plant Biology, 2009, 51(4): 423-432 (doi: 10.1111/j.1744-7909.2009.00812.x).

36. Zhang J., Wang Y., Wu S., Yang J., Liu H., Zhou Y. A single nucleotide polymorphism at the $V r n-D 1$ promoter region in common wheat is associated with vernalization response. Theoretical and Applied Genetics, 2012, 125(8): 1697-1704 (doi: 10.1007/s00122-012-1946-z).

37. Rigin B.V., Zveinek S.N., Bulavka N.V. Agrarnyi nauchnyi zhurnal, 1985, 427: 38 (in Russ.).

38. Bespalova L.A., Koshkin V.A., Potokina E.K., Filobok V.A., Matvienko I.I., Mitrofanova O.P., Guenkova E.A. Photoperiod sensitivity and molecular marking of genes Ppd and Vrn in connection with breeding alternative-habit wheat varieties. Russian Agricultural Sciences, 2010, 36(6): 389-392 (doi: 10.3103/S1068367410060017).

39. Wang L., Niu J.S., Li Q.Y., Qin Z., Ni Y.J., Xu H.X. Allelic variance at the vernalization gene locus Vrn-D1 in a group of sister wheat (Triticum aestivum) lines and its effects on development. The Journal of Agricultural Science, 2015, 153(4): 588-601 (doi: 10.1017/S0021859614000409).

40. Goncharov N.P. Sravnitel'naya genetika pshenits i ikh sorodichei [Comparative genetics of wheats and their relatives]. Novosibirsk, 2002 (in Russ.).

41. Košner J., Pánková K. Chromosome substitutions with dominant loci Vrn-1 and their effect on developmental stages of wheat. Czech Journal of Genetics and Plant Breeding, 2004, 40(2): 37-44.

42. Yan L., Helguera M., Kato K., Fukuyama S., Sherman J., Dubcovsky J. Allelic variation at the $V R N-1$ promoter region in polyploid wheat. Theoretical and Applied Genetics, 2004, 109(8): 1677-1686 (doi: 10.1007/s00122-004-1796-4).

43. Fu D., Szücs P., Yan L., Helguera M., Skinner J.S., von Zitzewitz J., Hayes P.M., Dubcovsky $\mathrm{J}$. Large deletions within the first intron in $V R N-1$ are associated with spring growth habit in barley and wheat. Molecular Genetics and Genomics, 2005, 273(1): 54-65 (doi: 10.1007/s00438004-1095-4).

44. Golovnina K.A., Kondratenko E.Ya., Blinov A.G., Goncharov N.P. Molecular characterization of vernalization loci VRN1 in wild and cultivated wheats. BMC Plant Biology, 2010, 10(1): 168 (doi: 10.1186/1471-2229-10-168).

45. Dubcovsky J., Loukoianov A., Fu D., Valarik M., Sanchez A., Yan L. Effect of photoperiod on the regulation of wheat vernalization genes VRN1 and VRN2. Plant Molecular Biology, 2006, 60(4): 469-480 (doi: 10.1007/s11103-005-4814-2).

46. Muterko A., Kalendar R., Salina E. Novel alleles of the VERNALIZATION1 genes in wheat are associated with modulation of DNA curvature and flexibility in the promoter region. BMC Plant Biology, 2016, 16(Suppl.): Article number 9 (doi: 10.1186/s12870-015-0691-2).

47. Muterko A.F., Salina E.A. Vavilovskii zhurnal genetiki i selektsii, 2017, 21(3): 323-333 (doi: 10.18699/VJ16.19-o) (in Russ.).

48. Santra D.K., Santra M., Allan R.E., Campbell K.G., Kidwell K.K. Genetic and molecular characterization of vernalization genes $V r n-A 1, V r n-B 1$, and $V r n-D 1$ in spring wheat germplasm from the Pacific Northwest region of the U.S.A. Plant Breeding, 2009, 128(6): 576-584 
(doi: 10.1111/j.1439-0523.2009.01681.x).

49. Shcherban A.B., Efremova T.T., Salina E.A. Identification of a new $V r n-B 1$ allele using two near-isogenic wheat lines with difference in heading time. Molecular Breeding, 2012, 29(3): 675685 (doi: 10.1007/s11032-011-9581-y).

50. Milec Z., Tomková L., Sumíková T., Pánková K. A new multiplex PCR test for the determination of Vrn-B1 alleles in bread wheat (Triticum aestivum L.). Molecular Breeding, 2012, 30(1): 317-323 (doi: 10.1007/s11032-011-9621-7).

51. Chu C.-G., Tan C.T., Yu G.-T, Zhong S., Xu S.S., Yan L. A novel retrotransposon inserted in the dominant $V r n-B 1$ allele confers spring growth habit in tetraploid wheat (Triticum turgidum L.). G3: Genes, Genomes, Genetics, 2011, 1(7): 637-645 (doi: 10.1534/g3.111.001131).

52. Zhang X., Gao M., Wang S., Chen F., Cui D. Allelic variation at the vernalization and photoperiod sensitivity loci in Chinese winter wheat cultivars (Triticum aestivum L.). Front. Plant Sci., 2015, 6: 470 (doi: 10.3389/fpls.2015.00470).

53. Takumi S., Koyama K., Fujiwara K., Kobayashi F. Identification of a large deletion in the first intron of the Vrn-D1 locus, associated with loss of vernalization requirement in wild wheat progenitor Aegilops tauschii Coss. Genes \& Genetic Systems, 2011, 86(3): 183-195 (doi: 10.1266/ggs.86.183).

54. Muterko A., Balashova I., Cockram J., Kalendar R., Sivolap Y. The new wheat vernalization response allele $\mathrm{Vrn}-\mathrm{D} 1 \mathrm{~s}$ is caused by DNA transposon insertion in the first intron. Plant Mol. Biol. Rep., 2015, 33(2): 294-303 (doi: 10.1007/s11105-014-0750-0).

55. Muterko A.F. Analiz polimorfizma genov VRN i PPD u tetraploidnykh i geksaploidnykh vidov roda Triticum L. Avtoreferat kandidatskoi dissertatsii [Analysis of VRN and PPD genes polymorphism in tetraploid and hexaploid species of the genus Triticum L. PhD Thesis]. Novosibirsk, 2017 (in Russ.).

56. Kippes N., Debernardi J.M., Vasquez-Gross H.A., Akpinar B.A., Budak H., Kato K., Chao S., Akhunov E., Dubcovsky J. Identification of the VERNALIZATION 4 gene reveals the origin of spring growth habit in ancient wheats from South Asia. Proceedings of the National Academy of Sciences, 2015, 112(39): E5401-E5410 (doi: 10.1073/pnas.1514883112).

57. Chen F., Gao M., Zhang J., Zuo A., Shang X., Cui D. Molecular characterization of vernalization and response genes in bread wheat from the Yellow and Huai Valley of China. BMC Plant Biology, 2013, 13: 199 (doi: 10.1186/1471-2229-13-199).

58. Nowak M., Leśniowska-Nowak J., Zapalska M., Banaszak Z., Kondracka K., Dudziak K., Kowalczyk K. Analysis of VRN1 gene in triticale and common wheat genetic background. Scientia Agricola, 2014, 71(5): 345-355 (doi: 10.1590/0103-9016-2013-0254).

59. Zaitseva O.I., Lemesh V.A. Genetika, 2015, 51(7): 766-774 (doi: 10.7868/S0016675815070140) (in Russ.).

60. Shcherban A.B., Emtseva M.V., Efremova T.T. Molecular genetical characterization of vernalization genes $V r n-A 1, V r n-B 1$ and $V r n-D 1$ in spring wheat germplasm from Russia and adjacent regions. Cereal Research Communications, 2012, 40(3): 351-361 (doi: 10.1556/CRC.40.2012.3.4).

61. Shcherban A.B., Börner A., Salina E.A. Effect of $V R N-1$ and $P P D-D 1$ genes on heading time in European bread wheat cultivars. Plant Breeding, 2015, 134(1): 49-55 (doi: 10.1111/pbr.12223).

62. Milec Z., Sumíková T., Tomková L., Pánková K. Distribution of different Vrn-B1 alleles in hexaploid spring wheat germplasm. Euphytica, 2013, 192(3): 371-378 (doi: 10.1007/s10681-0130863-9).

63. Likhenko I.E., Stasyuk A.I., Shcherban' A.B., Zyryanova A.F., Likhenko N.I., Salina E.A. Vavilovskii zhurnal genetiki i selektsii, 2014, 18(4/1): 691-703 (in Russ.).

64. Diaz A., Zikhali M., Turner A.S., Isaac P., Laurie D.A. Copy number variation affecting the Photoperiod-B1 and Vernalization-A1 genes is associated with altered flowering time in wheat (Triticum aestivum). PLoS ONE, 2012, 7(3): e33234 (doi: 10.1371/journal.pone.0033234).

65. Stelmakh A.F. Genetic effects of $V r n$ genes on heading date and agronomic traits in bread wheat. Euphytica, 1993, 65(1): 53-60 (doi: 10.1007/BF00022199).

66. Iqbal M., Navabi A., Yang R.-C., Salmon D.F., Spaner D. The effect of vernalization genes on earliness and related agronomic traits of spring wheat in northern growing regions. Crop Science, 2007, 47(3): 1031-1039 (doi: 10.2135/cropsci2006.09.0618).

67. Ukalska J., Kociuba W. Phenotypical diversity of winter triticale genotypes collected in the Polish gene bank between 1982 and 2008 with regard to major quantitative traits. Field Crops Research, 2013, 149: 203-212 (doi: 10.1016/j.fcr.2013.05.010).

68. Voronin A.N., Stel'makh A.F. Nauchno-tekhnicheskii byulleten' VSGI, 1985, 55: 19-23 (in Russ.).

69. Tishchenko V.N., Chekalin N.M., Panchenko I.A., Usova Z.V. Prodolzhitel'nost' vegetatsionnogo $i$ mezhfaznykh periodov $i$ ikh korrelyatsii s urozhainost'yu $v$ zavisimosti ot uslovii goda i genotipa ozimoi myagkoi pshenitsy [The duration of vegetation and interphase periods and their correlation with productivity depending on a year conditions and winter common wheat genotype]. Available: http://agromage.com/stat_id.php?id=409. Accessed: 7.10.2019 (in Russ.).

70. Würschum T., Liu W., Alheit K.V., Tucker M.R., Gowda M., Weissmann E.A., Hahn V., 
Maurer H.P. Adult plant development in triticale ( $\times$ Triticosecale Wittmack) is controlled by dynamic genetic patterns of regulation. G3: Genes, Genomes, Genetics, 2014, 4(9): 1585-1591 (doi: 10.1534/g3.114.012989).

71. Zhmurko V.V., Avksent'eva O.A., Zubrich A.I., Yukhno Yu.Yu., Petrenko V.A., Popova Yu.V., Samoilov A.M., Khan' Bin. Buletinul Academiei de tiin e a Moldovei, 2011, 3(315): $72-79$ (in Russ.).

72. Zhmurko V.V., Avksent'eva O.A., Khan' Bin. Fiziologiya rastenii i genetika, 2013, 45(5): 408-416 (in Russ.).

73. Koren' L.V., Khotyleva L.V. Vestnik fonda fundamental'nykh issledovanii, 2010, 4(54): 116-124 (in Russ.).

74. Stepochkin P.I. Study and utilization of spontaneous spring mutations of wheat, rye and triticale in Siberia. Proc. 14 $4^{\text {th }}$ Int. EWAC Conf. A. Börner, J.W. Snape (eds.). Istanbul, Turkey, 2007: 148-154.

75. Stepochkin P.I., Artemova G.V. Vestnik VOGiS, 2008, 12(4): 710-716 (in Russ.).

76. Oliver S.N., Finnegan E.J., Dennis E.S., Peacock W.J., Trevaskis B. Vernalization-induced flowering in cereals is associated with changes in histone methylation at the VERNALIZATION1 gene. Proceedings of the National Academy of Sciences, 2009, 106(20): 8386-8391 (doi: 10.1073/pnas.0903566106).

77. Li X., Liu Y. The conversion of spring wheat into winter wheat and vice versa: false claim or Lamarckian inheritance? Journal of Biosciences, 2010, 35(2): 321-325 (doi: 10.1007/s12038-0100035-1).

78. Loukoianov A., Yan L., Blechl A., Sanchez A., Dubcovsky J. Regulation of $V R N-1$ vernalization genes in normal and transgenic polyploid wheat. Plant Physiology, 2005, 138(4): 2364-2373 (doi: 10.1104/pp.105.064287).

79. Medvedev A.M., Poma N.G., Osipov V.V., Zhikharev S.D. Zernobobovye i krupyanye kul'tury, 2017, 3(23): 50-58 (in Russ.).

80. Popolzukhina N.A., Popolzukhin P.V., Yakunina N.A., Suponin M.S. Materialy Mezhdunarodnogo kongressa «Biotekhnologiya: sostoyanie i perspektivy razvitiya» [Proc. Int. Cong. «Biotechnology: current state and prospects». Vol. 2]. Moscow, 2017, tom. 2: 97-100 (in Russ.).

81. Krotova L.A. Vestnik Altaiskogo gosudarstvennogo agrarnogo universiteta, 2010, 2(64): 28-31(in Russ.).

82. Leonova I.N., Dobrovolskaya O.B., Kaminskaya L.N., Adonina I.G., Koren L.V., Khotyljova L.V., Salina E.A. Molecular analysis of the triticale lines with different Vrn gene systems using microsatellite markers and hybridization in situ. Russian Journal of Genetics, 2005, 41(9): 1014-1020 (doi: 10.1007/s11177-005-0193-7). 